\title{
NOTES ON CEREBELLAR ATAXIA IN CHILDHOOD
}

\author{
BY \\ ROBERT A. SHANKS \\ From the Department of Child Health, University of Glasgow, and the Royal Hospital for Sick \\ Children, Glasgow
}

(Received for Publication March 13, 1950)

The syndrome of cerebellar ataxia is one with which paediatricians are familiar not only because it is the usual presenting feature of the subtentorial tumours of childhood, but also because there is a small but well-recognized group of cases in which cerebellar ataxia is the only ultimate diagnosis. It is not proposed to catalogue all the causes of cerebellar ataxia in childhood but rather to discuss the diagnosis and prognosis of this latter group, most of which run a limited and benign course and in which so far, only an empirical diagnosis has been possible.

For this purpose it seemed worth while to analyse the case-sheets of such cases admitted to one medical unit at the Royal Hospital for Sick Children, Glasgow, during the past 20 years. The period chosen was from 1929 to 1949 inclusive, and during this time there were in all 39 cases of which it was possible to trace 30 . This paper is based upon an analysis of these cases.

It will be helpful first to define more precisely the conception of cerebellar ataxia. Lesions of the cerebellum and its pathways all produce a fundamentally similar picture, and although acute lesions result in a more pronounced hypotonia than slowly progressive or long-standing ones, the complex function of adapting to changing posture during voluntary movement is defective in all. It is this failure of adaption that constitutes cerebellar ataxia, a condition quite distinct from the incoordination resulting from purely sensory or motor disturbances.

The source of information in all cases investigated has been the case-record, but in those seen personally the details were verified by questioning the parents and patients concerned. A complete physical examination was carried out on each patient seen.

In analysing this material it was thought justifiable to use the total number of cases in assessing factors which were independent of the later progress of the condition. Prognostic factors on the other hand, concern only those patients who were traced.

The cases fell naturally into two groups, those with a sudden onset and those with an insidious onset, and the type of onset therefore has been used in classification. For convenience, those cases with a sudden onset will be termed Group I, and those with an insidious onset, Group II. Table 1 shows the main features of each. The two groups are fairly equally divided, and although there were more males than females in Group I, the small number of cases precludes any definite conclusion. Table 2 shows the seasonal incidence of the two groups. Group I cases appear to show a defined seasonal incidence in the late summer and winter which is not shown in Group II. How far one may be justified in adding this to the evidence in favour of a virus aetiology (especially that of anterior poliomyelitis), is perhaps arguable. Patients in whom

TABLE 1

Table of Cases Classified According to the TyPe OF ONSET OF Ataxia

\begin{tabular}{|c|c|c|c|}
\hline & & $\begin{array}{l}\text { Group I: } \\
\text { Sudden } \\
\text { Onset }\end{array}$ & $\begin{array}{c}\text { Group II: } \\
\text { Insidious } \\
\text { Onset }\end{array}$ \\
\hline $\begin{array}{l}\text { Total cases } \\
\text { males } \\
\text { females } \ldots\end{array}$ & $\begin{array}{l}\cdots \\
\cdots \\
\cdots\end{array}$ & $\begin{array}{r}22 \\
13 \\
9\end{array}$ & $\begin{array}{r}17 \\
8 \\
9\end{array}$ \\
\hline Antecedent illness .. & . & 6 & 1 \\
\hline Fever & $\cdots$ & 3 & 3 \\
\hline $\begin{array}{ll}\text { C.S.F. } & \text { abnormal } \\
\text { normal } & \ldots \\
\text { uninvestigated }\end{array}$ & $\begin{array}{l}\cdots \\
\cdots \\
\cdots\end{array}$ & $\begin{array}{r}4 \\
14 \\
4\end{array}$ & $\begin{array}{r}1 \\
13 \\
3\end{array}$ \\
\hline
\end{tabular}

TABLE 2

Table of Seasonal InCIDENCE

\begin{tabular}{|c|c|c|c|c|c|c|c|c|c|c|c|c|}
\hline Month & 吾 & 这 & $\sum^{\grave{\Sigma}}$ & 高 & $\stackrel{\lambda}{\Xi}$ & $\stackrel{\text { }}{\Xi}$ & $\stackrel{\lambda}{\equiv}$ & $\sum_{2}^{\infty}$ & 䒕 & ठั & z & : \\
\hline Group I & 2 & 2 & 0 & 0 & 2 & 1 & 0 & 2 & 3 & 4 & 4 & 2 \\
\hline Group II & 2 & 3 & 4 & 1 & 1 & 0 & 1 & 1 & 1 & 0 & 3 & 0 \\
\hline
\end{tabular}


the ataxia had a sudden onset were on the whole confined to a younger age-group than those with an insidious onset (Table 3). Out of the 22 cases in Group $I$, in 18 the onset was between the ages of 3 and 7 years, while only seven out of 17 in Group II began in this period.

TABLE 3

TABLE OF AGE INCIDENCE

\begin{tabular}{|c|c|c|c|c|c|c|c|c|c|c|c|c|c|c|}
\hline Year of age & 1 & 2 & 3 & 4 & 5 & 6 & 7 & 8 & 9 & 10 & 11 & 12 & 13 & 14 \\
\hline Group I & $\overline{0}$ & 0 & 3 & $\overline{6}$ & $\overline{6}$ & 1 & 2 & 0 & 2 & 1 & 0 & $\overline{0}$ & 0 & 1 \\
\hline Group II & 0 & 0 & 0 & 3 & 3 & 1 & 0 & 2 & 3 & 0 & 0 & 3 & 1 & 1 \\
\hline
\end{tabular}

\section{Ataxia with a Sudden Onset (Group I)}

The relation between the onset of acute cerebellar ataxia and an antecedent infection has frequently been commented upon. As early as 1872 Schepers reported a case following measles, and Caccia in 1904 reported its occurrence after varicella. Since then cases have been recorded after measles, rubella, variola, varicella, vaccinia, and also bacterial diseases such as typhoid, scarlet fever, whooping cough, and diphtheria. The position was reviewed by Dagnelie (1931). In general it seems that when this complication occurs it is always during or immediately following the antecedent illness and that the ultimate prognosis is good. Post-vaccinial encephalitis, however, is an exception in having a high mortality (Wilson and Ford, 1927). Acute cerebellar ataxia must therefore be accepted as one of the manifestations of post-infective encephalitis or encephalomyelitis. It is nevertheless not a frequent one and Sawchuk, LaBocetta, Tornay, Silverstein, and Peale (1949) when reviewing 50 cases of encephalomyelitis following measles recorded only one of acute ataxia.

In investigating the question of antecedent illness in the present series there appeared ample justification for restricting the term to illness occurring within three weeks of the onset of the ataxia. Using this criterion there were six cases in Group I in which there were possibly significant antecedent illnesses. These comprised one case of mumps, one of whooping cough, one of pneumonia, one of tonsillitis, one with an unspecified febrile illness, while the last had a febrile reaction to three doses of ' cold' vaccine in the preceding three weeks. It is evident that in this series at least, antecedent illnesses, and particularly virus infections, are numerically unimportant.

The most striking fact emerging out of the analysis of these cases is the association of the type of onset with the later progress of the condition (Table 4). The prognosis of cases in Group I was excellent with 13 complete recoveries out of 17 and one other
TABLE 4

Table of the Course of 30 Traced Cases

\begin{tabular}{|c|c|c|c|c|}
\hline Result & & & Group I & Group II \\
\hline $\begin{array}{l}\text { Well } \\
\text { Improved } \\
\text { Deteriorating } \\
\text { Died . . }\end{array}$ & $\begin{array}{l}\cdots \\
\cdots \\
\cdots\end{array}$ & $\begin{array}{l}\cdots \\
\cdots \\
\cdots\end{array}$ & $\begin{array}{r}13 \\
1 \\
2 \\
1\end{array}$ & $\begin{array}{r}1 \\
1 \\
10 \\
1\end{array}$ \\
\hline Total & . & $\ldots$ & 17 & 13 \\
\hline
\end{tabular}

greatly improved. Although nine of these recovered within three months of the onset of the ataxia, in some cases recovery was delayed even up to three years. In one patient, now 19 years of age, who made a rapid recovery, was later dux of his school and is now doing well at a university, there was a marked residual nystagmus. This was the only sequela seen in this group.

Ataxia with an Insidious Onset (Group II)

Because of the slow onset, a time relation between the ataxia and the antecedent illness is difficult to define. Using the criterion employed in Group I there was only one case in which an indefinite febrile illness preceded the onset of the ataxia.

The progress of the illness in this group presents a remarkable difference from that in Group I. In only two out of 13 cases was the outlook at all favourable; moreover in both of these there is some doubt whether they should not have been included in the other group. The first of these was a boy who gave a history of having had a febrile illness at the age of 10 months which was followed by a transient strabismus. Some months later when he began to walk he was noticed to be ataxic. This ataxia lasted some two to three years and when he was seen at the age of 12 years he appeared to have made a complete recovery. The second is also in many ways a mystery. A girl aged 13 years was seen on account of a gradually increasing ataxia. In addition to signs of cerebellar ataxia she had marked pyramidal tract involvement, some slight papilloedema, and a moderate lymphocytic exudate in her cerebrospinal fluid. The investigations of the neurosurgeon were inconclusive and no special treatment was undertaken. When seen last year at the age of 26 she had obviously improved to some extent and was able to walk unaided and to do light work. She still had some spasticity and extensor plantar responses but no ataxia and no papilloedema. It is tempting to suppose that this was a case of chronic arachnoiditis (Horrax, 1924) and would then more properly be classed with intracranial neoplasms. All the others have shown an inexorable progression 
of the disease and many cases, seen up to 20 years later, were classical examples of degenerative cerebello-spinal ataxia.

\section{Discussion}

It seems evident that the two groups of cases described in this series are not separated arbitrarily but represent two distinct syndromes. Of the second group there seems little doubt that most if not all belong to the degenerative ataxias of presumably genetic origin. It is interesting that in the early stages the clinical picture of the progressive cases differed in no way from that of the benign case except in the mode of onset. Neither the presence or absence of fever nor changes in the cerebrospinal fluid were helpful in diagnosis.

Of the nature of what we may term acute cerebellar ataxia (Group I) one can only guess. Even where an antecedent virus infection is incriminated the pathology is uncertain. There are three main views of their nature: that they constitute a straightforward inflammation of the brain by the virus concerned, or that they constitute an allergic reaction to the infection, or that they are the result of another virus infection wakened into activity by the preceding infection (Reisman and Rosen, 1943). Whatever the cause of these ' secondary' cases, the fact that acute cerebellar ataxia may occur de novo has also long been recognized (Batten, 1905 ; Griffith, 1916). It has been assumed that these also were related to a neurotropic virus, though their benign prognosis precluded even the indefinite support of histology. In spite of a tendency in the past to attribute to the virus of encephalitis lethargica all obscure encephalitis manifestations, there has been little to suggest that this is the virus of acute cerebellar ataxia, but Jenkins (1929) found five such cases in the literature which he reported with two of his own. One has also to consider the virus or viruses of anterior poliomyelitis of which the cerebellar form has often been described (Griffith, 1916; Grinker and Bucy, 1949). On the other hand it has been pointed out that the incidence of cerebellar ataxia is not increased during poliomyelitis epidemics, and moreover Klingman and Hodges (1944) have evidence that their cases were attributable neither to the virus of poliomyelitis nor to any other neurotropic virus investigated. Johnston and Goodpasture (1936) report a fatal case of cerebellar encephalitis resembling that of loupingill; however, evidence is lacking that the virus diseases of the central nervous system are often associated with acute cerebellar ataxia.

Dagnelie (1931) in his review found nothing to indicate the pathological basis of cerebellar ataxia beyond the assumption, either tacit or explicit, that it is always due to an encephalitis. In Klingman and Hodges' critical study (1944) the evidence is mainly negative. As well as failing to identify a specific virus they found signs of meningeal irritation (increased protein and cells in the cerebrospinal fluid) in only two out of seven cases, corresponding with the four out of 18 cases investigated in this series. It seems likely that encephalitis would show an abnormal cerebrospinal fluid more often.

Cerebellar ataxia in childhood evidently presents a number of problems that await solution, but nevertheless sufficient guidance can be obtained from the clinical pattern of these cases to establish criteria of prognosis. On the one hand, there is the case with the acute onset occurring most frequently in early childhood in which the ataxia is maximal at onset with a steady improvement leading to complete cure within a few months. On the other hand there is the case in which the ataxia begins gradually and increases slowly leading to complete invalidism.

\section{Summary}

Thirty-nine cases presenting with cerebellar ataxia over a period of 20 years are analysed. Thirty of these were traced and the outcome described.

The mode of onset of the ataxia was a most valuable prognostic indication. Those with a sudden onset had an almost uniformly benign course, while those in whom the ataxia began insidiously were mainly of the progressive type; there is little to distinguish the acute, benign case from the hopelessly progressive one except the onset.

I am grateful to Professor Stanley Graham for permission to report the cases under his care and for advice in the preparation of this paper.

\section{REFERENCES}

Batten, F. E. (1905). Brain, 28, 484.

Caccia, G. (1904). Riv. Clin. pediat., 2, 817. Cited by Miller and Davidson.

Dagnelie, J. (1931). J. Neurol. Psychiat., Brux., 31, 78. Griffith, J. P. C. (1916). Amer. J. med. Sci., 151, 24.

Grinker, R. R., and Bucy, P. C. (1949). 'Neurology, 4th ed., p. $646 . \quad$ Springfield, Illinois.

Horrax, G. (1924). Arch. Surg., Chicago, 9, 95.

Jenkins, A. (1929). Arch. Neurol. Psychiat., Chicago, 22, 469.

Johnston, L. M., and Goodpasture, E. W. (1936). Amer. J. Dis. Child., 52, 1415.

Klingman, W. O., and Hodges, R. G. (1944). J. Pediat., $24,536$.

Reisman, H. A., and Rosen, A. S. (1943). Amer. J. Dis. Child., 66, 597.

Sawchuk, S., LaBocetta, A. C., Tornay, A., Silverstein, A., and Peale, A. R. (1949). Amer. J. Dis. Child., 78, 844.

Schepers, M. A. (1872). Berl. klin. Wschr., 9, 517.

Wilson, R. E., and Ford, F. R. (1927). Bull. Johns Hopk. Hosp., 40, 337. 